\title{
KREDIBILITAS KOMUNIKATOR PADA DESTINASI WISATA MELALUI MEDIA SOSIAL (VIDEO VIRAL NEGERI DI ATAS AWAN CITOREK BANTEN)
}

\author{
Tono Purwantoro \\ Universitas Al Azhar Indonesia
}

Naskahditerima tanggal 14-07-2020, direvisi tanggal 27-07-2020, disetujui tanggal 30-07-2020

\begin{abstract}
Abstrak. Telepon seluler (gawai) menjadi kebutuhan primer bagi masyarakat. Khalayak membutuhkannya sebagai sarana informasi, bersosialisasi atau pengungkapan diri dalam berkomunikasi. Arus pesan komunikasi melalui aplikasi instant messaging WhatsApp meningkat dan menduduki posisi pertama. Informasi yang disebarkan melalui WhatsApp sering menjadi viral. Misalnya peristiwa fenomenal tayangan video mengenai wahana wisata baru bernama Negeri Di Atas Awan, Citorek, Banten pada September 2019. Komunikator dalam tayangan adalah Pemimpin Daerah yang tidak disebutkan namanya namun komunikasi visual dalam video dan narasi yang diunggah berhasil memikat hati penerima pesan dan memviralkannya. Dalam hitungan hari, viral tayangan video lanjutan berisikan antusias masyarakat yang berkunjung. Namun, pengunjung kecewa karena mendapati fakta yang berbeda. Penelitian ini ingin melihat bagaimana kredibilitas komunikator pada destinasi wisata yang viral melalui media sosial. Penelitian menggunakan metode studi dokumen dengan pendekatan kualitatif desktiptif. Temuan menunjukkan, kredibilitas komunikator pada media digital menjadi kekuatan sesuai pernyataan McCorskey ada tiga nilai yaitu keahlian, karakter, dan kedinamisan yang tersajikan melalui komunikasi audio visual. Namun demikian, perlu diperhaikan cermat sehingga tidak menjadi kecewa. Kerelaan publik memviralkan menyebabkan kepanikan, dimana realitas yang tersaji dalam komunikasi visual tidak sesuai harapan yang dilihatnya. Kekuatan penyebaran pesan komunikasi visual melalui media aplikasi sosial hadir seperti dalam the bullet theory, pesannya cepat memiliki daya tarik antusiasme publik.
\end{abstract}

Kata kunci: aplikasi whatsapp, komunikasi viral, komunikasi visual, media sosial

Abstract. Cellular or mobile telephones for Indonesian people become the primary needs now. The audience needs it as a means of information, socializing or self-disclosure in interpersonal and group communication. The mobile phone used is increased.especialy use of WhatsApp (WA) instant messaging application which occupies the first position in Indonesia. Information distributed by WA immediately went viral such as the phenomenal event called Negeri Di Atas Awan, Citorek, Banten. The communicator in this video is the local Governor, but the visual communication and its narrative succeeded in capturing the heart of people were willing to see it. But then the visitors are disappointed to find different facts. This study wants to see how the communicator's credibility in tourist destinations through social media. The research used the document study method with a qualitative descriptive approach. The result is the credibility of communicator on digital media becomes a strength according to McCorskey's statement there are three values, namely expertise, character, and dynamism which are presented through audio-visual communication. The power of spreading visual communication messages through social media applications is present as in the bullet theory, the message quickly has the appeal of public enthusiasm.

Keywords: social media, viral communication, visual communication, whatsapp aplication. 


\section{PENDAHULUAN}

Proses penyampaian isi pesan komunikasi melalui aplikasi media sosial terutama menggunakan aplikasi instant messaging (IM) semakin marak dilakukan publik, termasuk publik di Indonesia. Pada era sebelum internet popular, mereka umumnya melakukan interaksi komunikasi secara tatap muka atau jika jaraknya jauh, menggunakan saluran media pesawat telepon. Melalui penggunaan saluran telepon, komunikasi dapat segera diwujudkan sehingga dapat menumbuhkan namun dengan konsekuensi biaya mahal. Keberadaan internet dan smartphone sepertinya menjadi pelengkap kebahagiaan publik atau masyarakat Indonesia yang senang bersosialisasi melalui komunikasi. Kenney (2009:1) mendefinisikan bahwa communication as a social process. Communication is social because it involves interactions between people. Communication is a process because it consists of an ongoing series of exchange. In these exchange, one person uses symbols to intentionally send a message; then others interpret the message's meaning and respond. Komunikasi merupakan kegiatan sosial, interaksi antara orang untuk pertukaran gagasan, pemikiran dan mengintepretasikan makna pesan yang disampaikan dan memberikan feedback.

Salah satu media komunikasi saat ini adalah media digital seperti mobile atau smartphone. Menurut media Kompas.com (2019), pemilik smartphone atau gawai di Indonesia pada kuartal kedua 2019 mencapai 9,7 juta. Pengguna telepon selular (ponsel) menurut databoks mencapai 371,4 juta atau 142 persen dari total populasi sebanyak 262 juta jiwa. Angka tersebut tentunya akan terus berkembang seiring dengan tingkat daya beli masyarakat. Interaksi sosial dalam berkomunikasi pun akan mengalami banyak perubahan termasuk dalam menggunakan berbagai aplikasi media sosial yang dapat diunduh secara gratis seperti WhatsApp, sebuah aplikasi media sosial yang dapat berinteraksi melalui video call sehingga dapat melakukan face to face communication maupun cukup terpuaskan melalui pengiriman atau pun menerima pesan tulisan (text).

Perkembangan teknologi media sosial atau aplikasi chat seperti WhatsApp membawa perubahan besar dalam berkomunikasi. Kehadiran media baru (New Media) ini membawa perubahan besar dalam kehidupan manusia, termasuk dalam bidang pemasaran. Dewdney dan Ride (2006:20) mendefinisikan new media atau media baru sebagai tatanan teknologi komunikasi baru berbasis komputer yang terkait dengan konteks kultural dan praktik media. Tumbuhnya teknologi komunikasi digital membawa perubahan besar terhadap kegiatan sosial dan berbagai aspek ekonomi hingga ke aneka industri. Internet menjadi kebutuhan yang tidak dapat ditinggalkan. Terbukti pengguna internet masyarakat Indonesia terus meningkat. Data APJII atau Asosiasi Penyelenggara Jasa Internet Indonesia terakhir yang cukup lengkap menunjukan bahwa pengguna internet di Indonesia meningkat menjadi 171.17 juta jiwa atau $64,8 \%$ dari seluruh populasi Indonesia (Survey APJII, 2018). Berdasarkan laporan terbaru We Are Social, pada tahun 2020 disebutkan bahwa ada 175,4 juta pengguna internet di Indonesia. Dibandingkan tahun sebelumnya, ada kenaikan $17 \%$ atau 25 juta pengguna internet di negeri ini. Berdasarkan total populasi Indonesia yang berjumlah 272,1 juta jiwa, maka itu artinya $64 \%$ setengah penduduk RI telah merasakan akses ke dunia maya (Dikutip dari Agus Tri Haryanto-detikInet. Kamis, 20 Februari 2020. "Riset: Ada 175,2 juta Pengguna Internet di Indonesia", diakses dari https://inet.detik.com/cyberlife/d-4907674/riset-ada-1752-jutapengguna-internet-di-indonesia).

Perkembangan internet menghasilkan teknologi baru dalam chat apps atau lebih popular dengan sebutan Instant Messaging (IM). WhatsApp yang sering digunakan masyarakat Indonesia dalam beraktivitas komunikasi merupakan media lengkap karena membuat si pemilik telepon selular memiliki kemudahan dalam berinteraksi. Banyak yang menggunakan untuk kepentingan bersosialisasi maupun sebagai penyampaian pesan baik oleh individu maupun kelompok (Trisnani: 2017). WhatsApp merupakan produk pesan instan yang dimiliki Facebook setelah dibeli seharga US\$19 Miliar atau sekitar Rp 200 triliun. (Kompas.com, 13 Februari 2020) Menurut Dailysocial.id, didirikan sejak 24 Februari 2009 oleh Brian Actom dan Jan Koum. Pada Februari 2013 mereka yang mengupload aplikasi ini baru 200 juta. Pada April 2014 mencapai 500 juta dan September 2015 menyentuh angka 900 juta. Hingga saat ini WhatsApp menjadi pilihan utama untuk memenuhi sarana komunikasi, dan terus meningkat 
hingga kini. Mengutip tulisan kompas.com, 13/02/2020, 18:19 wib, dalam tulisannya yang berjudul "whatsapp tembus 2 miliar pengguna". Dalam artikel ini dijelaskan bahwa pengguna whatsapp tembus ke angka dua miliar pengguna secara global. Hal itu diumumkan whatsapp melalui blog resminya

(Diakses dari https://tekno.kompas.com/read/2020/02/13/18190017/whatsapp-tembus-2-miliarpengguna). Sementara itu mengutip dari artikel Liputan6.com, 18 November 2019 mengenai "83 Persen Pengguna Internet Indonesia Pakai Whatsapp", dijelaskan menurut data Digital Report 2019 dari We Are Social dan Hootsuite, tercatat 83 persen pengguna internet di Indonesia merupakan pengguna WhatsApp (Diakses dari https://www.liputan6.com/tekno/read/4113678/83-persen-pengguna-internet-indonesia-pakaiwhatsapp). Ini menunjukkan bahwa aplikasi ini saat ini menjadi medium dominan yang digunakan oleh sebagian besar masyarakat Indonesia dalam berkomunikasi, termasuk juga banyak digunakan untuk komunikasi viral dan penyampaian pesan visual melalui fitur videonya.

Keberadaan aplikasi chat atau instant messaging, menurut Ramirez, Dominick, Fearter dan Lin seperti dikutip Rakhmat (2016:237) merupakan salah satu jenis layanan komunikasi melalui internet yang umum dan popular yang memungkinkan penggunanya membuat ruang chat pribadi atau grup. Whiting dan Williams (2013) seperti dikutip La Moriansyah (2015) berpendapat bahwa bagi individu motivasi menggunakan media sosial adalah mencari informasi, berbagi informasi, hiburan, relaksasi, dan interaksisosial. Satu diantaranya yang paling banyak digemari di Indonesia adalah media sosial berbasis aplikasi instant messaging WhatsApp.

WhatsApp menjadi fokus penelitian karena aplikasi ini menurut hasil penelitian menempati angka teratas dibandingkan lainnya seperti Line, BBM, Facebook messanger, dan WeChat. Data chat apps/Instant Message yang paling banyak digunakan di Indonesia, menurut Olivia Putri, PR \& Communication Manager SEA Cuponation, Indonesia, seperti dikutip Wardani, 25 Juni 2019, diduduki WhatsApp dengan tingkat penetrasi 83\% mengalahkan Line (59\%), Facebook (47\%), BBM (38\%) dan aplikasi WeChat (28\%). (Dikutip dari https://www.liputan6.com/tekno/read/3998745/ini-5-aplikasi-chatting-terpopuler-di-indonesia)

Keberadaan WhatsApp banyak digemari masyarakat Indonesia karena fitur aplikasinya dapat mengirim dan menerima visual, baik berisikan pesan video maupun foto. Fitur dan daya tarik yang dimilikinya mampu membawa perubahan dalam berkomunikasi. Kegiatan individu pun bervariasi, tidak hanya mengirimkan atau menerima isi pesan tertulis atau teks tetapi dapat pula berkomunikasi secara visual, baik saat berkirim maupun menerima isi pesan.

Salah satu elemen dalam komunikasi adalah komunikator. Kredibilitas komunikator dalam penyampaian isi pesan komunikasi merupakan faktor utama agar diterima baik komunikan. Kovacic (2010) menjelaskan, kredibilitas terhadap sumber berkaitan dengan kepercayaan individu yang menulis berita atau menyampaikan informasi. Namun demikian, tidak selamanya faktor tersebut memberikan pengaruh yang besar terhadap makna pesan yang disampaikan, termasuk apabila disampaikan melalui video WhatsApp (WA).

Kaitan antara pola kecepatan informasi, kemudahan berbagi informasi dan peran komunikator melalui aplikasi media chat seperti WA dapat dilihat dalam kasus berikut. Satu hari setelah meninggalnya Presiden Republik Indonesia keempat, B.J. Habibie, pada 9 September 2019 beberapa group WhatsApp mem-viral-kan atau saling berbagi tayangan video berdurasi 1:47 menit mengenai tempat wisata baru bernama Negeri Di Atas Awan, Gunung Luhur, Citorek, Banten. Isi pesan komunikator pada WA grup tidak menyebutkan siapa sosok komunikator yang bertutur mengenai ada lokasi wisata baru dekat dengan kota Jakarta yaitu di Desa Ciusul, Citorek, Kidul, Cibeber, Banten, Jawa Barat. 


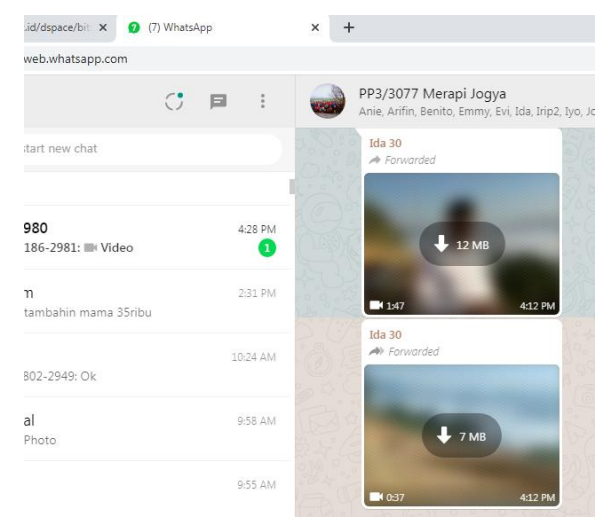

Sumber : Arsip WA Penulis

Gambar 1: Video Tentang Negeri di Atas Awan

Pesan komunikator yang disampaikan langsung tanpa teks mengenai daya tarik pesona tempat yang dipadati sekumpulan awan yang terlihat indah sehingga nampak menakjubkan bagi yang memandangnya karena awan tersebut berada di bawah orang yang menyaksikannya. Seperti saat kita berada di pesawat terbang di atas ketiggian beratus-ratus meter dari daratan. Tampilan visual video yang disuguhkan sangat memikat. Peristiwa yang disaksikan tersebut mampu memenuhi persyaratan nilai berita karena tempat yang dibicarakan masuk kategori kejadian yang menakjubkan atau hal yang tidak biasa.

Isi pesan komunikator melalui tayangan tersebut mampu menumbuhkan self interest, yaitu topik yang disampaikan komunikator berhubungan dengan penerima pesan, terutama para penikmat rekreasi sehingga memikat perhatian bagi yang melihatnya dan bisa menggugah ingin mengunjungi. Keindahan alam yang terekam video tersebut mampu menyentuh atau memiliki human interest sehingga menggiring penerima pesan untuk berbagi.

Kasus unggahan pesan komunikator melalui video kemudian diunggah ke media sosial menarik penulis untuk menganalisisnya melalui penelitian ini dari sudut pandang komunikator sebagai pembawa isi pesan. Pada fenomena video viral destinasi tempat wisata, Negeri Di Atas Awan di daerah Citorek, Banten tersebut tidak mencantumkan atau menyebutkan nama pembawa pesan tetapi pesannya beredar luas. Tidak hanya sebatas di kalangan WA grup tetapi mampu menarik media menuliskan dan menampilkan sosok komunikator tersebut dalam pemberitaannya.

Kekuatan komunikator dalam menyampaikan isi pesannya mampu menggiring publik datang menyaksikan lokasi yang dipaparkannya sehingga terjadi peristiwa yang mencengangkan. Kondisi tempat wisata tersebut ternyata belum seperti yang dibayangkan publik. Jalan menuju lokasi belum mulus serta prasarana tempat kunjungan yang belum tertata, sehingga membuat kemacetan. Arus lalu lintas padat bahkan tidak dapat bergerak. Keingintahuan publik seketika berubah menjadi kecewa. Rasa kecewa publik pun kembali dishare melalui grup WA dan bahkan sampai ke berbagai media baik media sosial maupun media online. Gegara komunikator tidak menjelaskan lebih lanjut mengenai prasarana jalan yang belum layak ataupun prasarana yang ada secara lugas. 


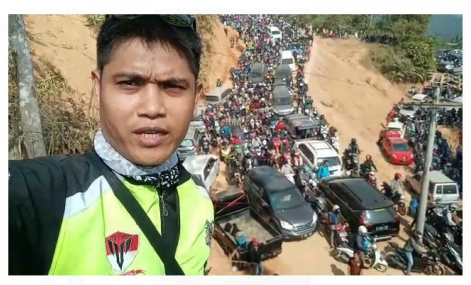

Sumber: pesan WA grup

Gambar 2: Pesan WA grup tentang kemacetan di Citorek

Pilihan sarana destinasi wisata saat ini sangat beragam dan menunjukkan kesadaran bagi para kepala daerah dalam memperkenalkan wilayah mereka sebagai tempat yang berpotensi mendapat kehadiran para tamu promosi pariwisata. Kesadaran kepala daerah akan potensi wilayahnya yang memiliki nilai jual bagi wisatawan domestik maupun mancanegara menjadi penting mengingat tempat wisata yang memiliki potensi tersebut perlu dijual agar mendapat nilai ekonomi bagi pendapatan wilayahnya. Salah satu caranya adalah melalui media sosial seperti Instagram atau pun penggunaan Whatsapp agar informasinya menjadi buzz. Cara ini memanfaatkan Word of Mouth, istilah lainnya dikenal dengan buzz, atau viral.

Harjanto (2009: 126) memberikan pemahaman viral dengan istilah getok tular, dimana proses komunikasi yang terjadi adalah komunikasi antarpribadi sehingga berbentuk sirkular. Proses komunikasi berlangsung bergantian antara komunikator dengan komunikan. Tujuan komunikasi viral adalah agar dalam waktu singkat penyebaran informasi dapat diketahui publik secara meluas melalui isi pesan yang menarik, sehingga mampu menarik perhatian publik atau konsumen. Pemicu orang melakukan getok tular menurut Harjanto (2009:125) sebagai cara mengurangi ketidakpastian. Pencarian informasi dengan bertanya kepada teman, tetangga, atau keluarga, menjadikan informasi menjadi lebih dapat dipercaya.

Oleh karena itu, seorang komunikator saat melakukan upload content senantiasa berupaya agar pesannya menarik komunikan. Menurut Mark Hughes yang dikutip Harjanto (2009), kunci yang memungkinkan pesan beredar di antara para anggota komunitas adalah pesan yang menarik perhatian dan memberikan mereka sesuatu yang dapat dinikmati pada saat dibicarakan. Pesan ini dinikmati pada saat-saat berbagi rasa dengan orang lain untuk menghibur, untuk kelihatan lebih pintar, atau cerdik, atau untuk ikut dianggap terlibat dengan pesan tersebut. Pelaku getok tular dengan senang hati menyebarluaskan sesuatu pesan, karena mereka mendapatkan kesempatan atau tempat untuk dibicarakan.

Utami (2017) melalui tulisannya The Role of Viral Video in Indonesia, mengutip pernyataan Nahon dan Hensley (2013), viralty is a result of people sharing information from one to another. It is different to broadcast transmission that spreads information from a central point (producers) to many people (audiences). Sedangkan Wardhana dan Pradana (2016) mengutip pernyataan Ferguson (2018:179) viral marketing is something created by the companies themselves to promote their products in the hope that saw him will be impressed and wiling to deliver it to colleagues and family.

Peristiwa di tempat wisata yang dijanjikan, Negeri Di Atas Awan Ciusul, Citorek Kidul, Banten. sangat memungkinkan menjadi viral karena komunikasi visual yang disuguhkan mengenai destinasi wisata yang didapatnya sangat menarik. Mereka yang mendapatkan pesan senantiasa berupaya memviralkan kembali kepada kelompok lainnya sehingga menjadi pembicaraan sesama anggota komunitas atau anggota kelompok WhatsApp tersebut.

Tayangan video berisi pesan wisata menjadi viral karena seringkali pesan dalam video tersebut menyuguhkan keutamaan keindahan visualisasi yang menjadi harapan yang menyegarkan bagi city branding lokal atau mereka para penikmat wisata. Agar dapat menarik publik maka pesona suguhan pesan yang disampaikan dalam berbagai media promosi tersebut 
harus dapat mendorong minat publik untuk meneruskan pesan kepada pihak atau rekan lainnya sehingga menjadi viral. Aktivitas tersebut saat ini sangat dimudahkan karena peran media sosial yang mudah diunduh kemudian digunakan.

Kemudahan dan kepraktisan penggunaan media sosial sebagai aplikasi untuk berkomunikasi dengan sesama teman sejawat atau satu grup merupakan fenomena tersendiri. Peran keunggulan chat apps atau instant messaging (IM) membuat tingginya penggunaan berbagai media tersebut serta membuat memudahkan pengiklan untuk mencapai target audiensnya dengan beragam cara dan didukung oleh kapabilitas multimedia yang luar biasa.

"The easiest way to communicate over the internet in real time and has become increasingly popular as a smartphone and tablet app, with free IM services supplanting costly text messages. Major IM services-many with voice and video chat capabilities-include Google Chat (through its email service, Facebook Chat, Microsoft's Skype, AOL Instant Messenger (AIM), Yahoo's Messenger, and Apple's iChat. IM users fill out detailed profiles when signing up to service, providing advertiser with multiple ways to target them as they chat with their friends. IM has evolved and expanded with the internet, embracing multimedia capabilities with apps like Snapchat, a photo messaging service that thrives on the cultural popularity of sending "selfies" and captions to friends. The images erase themselves in one of ten seconds, depending on the user's settings. In 2014 (after reportedly offering \$3 billion to buy Snapchat in a failed deal the year before), Facebook paid \$19 billion for WhatsApp, a cross-platform IM service that now has more than 800 million users worldwide." (Campbell: 2016:46)

Isi pesan komunikasi visual dalam video yang viral Negeri Di Atas Awan ini, dari sudut pandang ICT (Information Communication Techology) merupakan upaya baru dalam komunikasi pariwisata. Hal ini karena fenomena dan keterkaitan antara kecepatan teknologi ICT dan komunikasi pariwisata saling memberikan dukungan yang kuat dan berdampak kepada jumlah kunjungan wisatawan. ICT sangat erat kaitannya dan dapat men-support terhadap aktivitas tourism. Sahin dan Sengun (2015) menjelaskan, "new communication and information technology is also closely related to the tourism sector. Technologiec novelties help tourism services with high competitiveness." Sementara (Cao, Yu dan Tian, 2017) menegaskan jika dibandingkan dengan media tradisional, seperti majalah dan suratkabar, perkembangan media sosial tidak ditemani temuan baru atau teknologi. "Social media is an information transmission tool based on hynperlink and hypertext; it increases the engagement and interactivity of Internet users by allowing them to create contents themselves and changes the traditional mass media of single-way to the stage of two-way communication and interaction; so it has a more significant effect on society than any other traditional media."

Holden (2006, 11) memberikan definisi mengenai pariwisata (tourism) sebagai, "Tourism is essentially about people and places, the places that one group of people leave, visit and pass through, the other groups who make their trip possible and those that they encounter along the way." Pariwisata merupakan sekumpulan orang dan berbagai tempat, beragam tempat yang mereka tinggalkan, kunjungi atau mereka hanya melewati tempat yang ditinggalkan oleh sekelompok orang, mengunjungi dan melewati, kelompok-kelompok lain yang memungkinkan perjalanan mereka dan yang mereka jumpai di sepanjang jalan.

Dalam konteks promosi pariwisata, salah satu yang penting adalah penggunaan strategi viral marketing. Viral atau diistilahkan dengan buzz atau di Indonesia lebih dikenal sebagai getok tular seringkali digunakan dalam kegiatan pemasaran. Viral marketing merupakan upaya penyampaian pesan komunikasi dari satu orang ke orang lain. Viral marketing menurut Campbell (2016:388) adalah "short videos or other content that (marketers hope) quickly gains widespread attention as users share it with friends online or by word of mouth". Maksudnya adalah berupa video singkat atau isi lainnya (harapan penjual) dengan segera meluas perhatian sebagai users untuk men-share kepada teman online atau melalui mulut ke mulut. Kini, seiring dengan perkembangan internet, viral menjadi bagian yang mudah dilakukan siapa pun, kapan pun dan dari mana pun. Seperti dijelaskan. Kerin (2013:557) bahwa "internetenabled capabilities also make possible buzz, a popular term of word-of-mouth behavior in marketsgpace. Internet technology has magnified its significance". Kemampuan teknologi internet atau digital memudahkan kegiatan buzz, sebagai bentuk istilah penyampaian pesan atau kegiatan dan perilaku promosi melalui mulut ke mulut dalam wilayah pemasaran. Ini 
adalah peranan yang sangat signifikan dari teknologi internet atau digital. Kerin kemudian mengutip ucapan Jeff Bezos, president of Amazon.com bahwa jika anda memiliki pelanggan yang tidak puas di internet, ia tidak akan menceritakannya kepada enam temannya, ia akan menceritakannya ke 6.000 teman-temannya (Kerin, 2013:557).

Menurut Kerin (2013:558) "Viral marketing is an Internet-enabled promotional strategy that encourages individuals to forward marketer-initiated messages to others via e-mail, social networking websites, and blogs". Maksud Kerin adalah bahwa teknologi internet memudahkan strategi promosi yang mendorong individu untuk meneruskan isi pesan ke yang lain melalui email, social networking websites dan blog.

Namun demikian, penelitian ini lebih memfokuskan utuk membahas mengenai kredibilitas peran komunikator yang mampu mendorong pembaca IM (instant messaging) untuk tergerak berwisata ke tempat baru tersebut karena pesan yang disebarkan melalui komunikasi visual video di aplikasi WA tersebut. Apakah kredibilitas komunikator yang tampil di media berbasis digital melalui pesan komunikasi visualnya mampu mendorong antusiasme publik untuk melakukan suatu tindakan? Ini menjadi pertanyaan yang menarik, terutama dalam industri pariwisata.

\section{METODE PENELITIAN}

Penelitian ini menggunakan paradigma interpretif agar dapat menjawab berbagai pertanyaan seputar fenomena keriuhan publik saat berkunjung ke tempat hits yang ramai dibicarakan di media sosial. Paradigma interpretif. Paradigma penelitian yang dipilih dalam penelitian ini adalah paradigma interpretif. Interpretif adalah analisis sistematis akan tindakan sosial melalui observasi langsung dalam setting natural untuk mencapai pemahaman dan interpretasi bagaimana orang menciptakan dan mempertahankan dunia sosialnya (Neuman, 2006 : 88). Penelitian mengenai viral berita Negeri Di Atas Awan, Gunung Luhur, Banten, Jawa Barat menggunakan paradigma interpretatif. Tujuannya untuk mendapatkan hasil penelitian ini melalui analisis teks tertulis dan observasi melalui berbagai media massa dan kiriman komunikasi viral dari beberapa kelompok WhatsApp.

Sifat Penelitian untuk melaksanakan penelitian terhadap destinasi wisata tersebut, penulis menggunakan metode kualitatif. Tujuannya agar peneliti dapat mengeksplorasi fenomena atau kasus yang diteliti. Sifat penelitian eksploratoris yaitu investigasi yang terinspirasi dari petunjuk dan dugaan awal (Crano, Brewer, 2002 : 13).

Teknik Pengumpulan Data melalui Studi dokumen. Dokumen mengacu kepada berbagai sumber yang berbeda dari dokumentasi atau material seperti dokumen pribadi, fotografi, dokumen resmi, sumber internet, media massa (Bryman, 2012, chap.23). Menurut Bryman, dokumen akan mengungkapkan sesuatu mengenai realitas sosial. Dokumen juga dapat berbentuk tulisan, catatan, suara, gambar, dan digital (Daymon, Holloway, 2008 : 344).

Penelitian ini menggunakan desain penelitian studi kasus. Studi kasus menurut Harrison, Birks, Franklin \& Mills (2017) berakar dari tradisi sosiologis dan antropoligis yang mencoba memahami bagaimana orang hidup, memiliki pengalaman dan bagaimana mereka memahami dunia sosial dan budaya mereka. Tujuan penelitiannya untuk mendapatkan makna atas pengalaman tersebut dan konstruksi dunia yang dihadirkan. Merriam (2009) yang dikutip Harrison, Birks, Franklin \& Mills (2017) menggambarkan studi kasus dengan ciri : partikularistik, deskriptif, heuristic, menekankan tujuan dan sifat kualitatif, fokusnya spesifik, mencoba memahami dan mendeskripsikan temuan.

Yin (2014) menjelaskan dua bagian definisi yang berfokus kepada scope, proses, partikular, dan karakteristik metodologi dalam riset studi kasus, menekankan aspek empiris dalam risetnya, pentingnya memahami konteks kasus. Biasanya penelitian ini menggunakan kasus tunggal, melihat kativita skasus tersebut dan memahami aktivitas dalam situasi tertentu. Merriam (2009) menambahkan bahwa penelitian studi kasus mendeskripsikan kedalaman analisis, melihat faktor-faktor dari lingkungan yang memperngaruhi kasus. Kasus menjadi objek kajian, bisa merupakan individu atau komunitas (Dalam Harrison, Birks, Franklin \& Mills, 2017). Menurut Harrison, Birks, Franklin \& Mills (2017), studi kasus dapat merupakan metode 
atau prosedur penelitian (Yin, 2014), desain penelitian (Cresswell, 2014), atau strategi penelitian.

Sifat atau jenis penelitian ini adalah deskriptif. Menurut Neuman (2014), penelitian deskriptif adalah penelitian yang menggambarkan secara detil gambaran suatu kondisi, setting sosial, hubungan, atau menyajikan suatu data, membuat kategorisasi atau klasifikasi fenomena yang dikaji menjelaskan tahapan atau proses, menggambarkan latar belakang situasi atau konteks. Biasanya penelitian ini juga digunakan untuk atau dalam pengambilan keputusan atas suatu kebijakan. Penelitian deskriptif dimulai dari mendefinisikan isu. Hasil penelitian ini adalah berupa gambaran atau penjelasan atas suatu isu yang merupakan jawaban atas pertanyaan penelitian. Biasanya pertanyaannya adalah 'bagaimana' dan 'siapa yang terlibat'.

\section{HASIL PENELITIAN}

Media sosial WhatsApp merupakan instant message yang banyak digemari di Indonesia karena memiliki beragam fitur yang tersedla serta mudah penggunaannya. Kemudahan tersebut menjadikan aplikasi ini sangat berpengaruh dalam kepemilikan dan penggunaannya. Jika aplikasi banyak digunakan orang maka orang cenderung ingin menggunakannya karena akan memudahkan dalam interkasi komunikasi. Berbeda jika kepemilikannya hanya dimiliki segelintir orang, maka akan terbatas juga jumlahnya walaupun dapat memberikan ekslusif bagi pemiliknya. Sejarah mencatat, saat booming BBM (Blackberry Messager) di Indonesia, maka semakin banyak orang memilikinya untuk memanfaatkan produk tersebut sebagai sarana berkomunikasi. Jika tidak popular digunakan maka masyarakat akan ditiinggalkan seperti hancurnya produk Blackberry yang memulai aplikasi instant messenger. Seperti ditulis Kumparan 19 April 2019 dengan judul Perjalanan Blackberry Messenger: Disukai, Dijual, Lalu ditinggalkan. Dalam beritanya, aplikasi pesan instan Blackberry Messanger (BBM) akan resmi berhenti beroperasi pada 31 Mei 2019.

Kemudahan dan banyaknya masyarakat Indonesia pengguna aplikasi WA, maka meneruskan atau menularkan pesan melalui aplikasi ini ke rekan lainnya akan sangat efektif dan efisien. Seperti diungkap dalam penelitian Rahartri (2019) yang sependapat dengan pendapat Pranajaya dan Hendra Wicaksono (2017) bahwa pengguna memilih WA karena aplikasinya menyediakan berbagai kemudahan dan gratis. Tentunya mendorong penerima pesan sangat mudah untuk melanjutkan dan memviralkan pesan yang diterimanya. Alasan ini pula, membuat komunikator memilih medium ini sebagai alat menyampaikan pesannya.

Seorang komunikator diharapkan memiliki kredibilitas yang mumpuni saat berkomunikasi agar para pengguna media WhatApps terutama yang tergabung pada kelompok tertentu atau grup memviralkan pesan yang diterimanya. Seperti yang terjadi pada peristiwa 19 September 2019, pemilik WA banyak mendapat kiriman posting-an atau share dari berbagai rekannya mengenai destinasi yang mereka sebut sebagai negeri di atas awan.

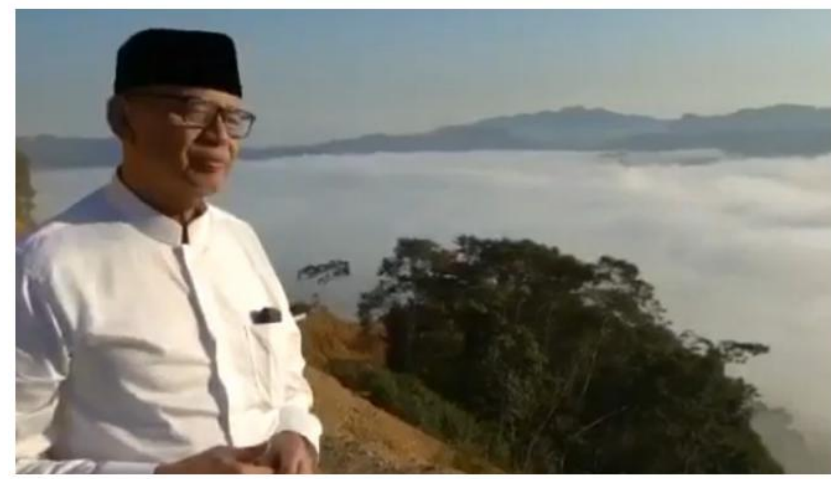

Sumber : Arsip WA Penulis

Gambar 3: Video Tentang Negeri di Atas Awan

Melalui tayangan video yang beredar, seorang pria turun dari kendaraan bersama beberapa orang lainnya dalam rombongan kendaraan, kemudian ia berorasi layaknya reporter 
televisi namun tanpa menyebutkan identitasnya, berdiri menghadap kamera kemudian mengalihkan pandangannya ke arah hamparan awan dengan mengucapkan beberapa rangkaian isi pesan seperti berikut,

“...bersama dengan para santri berdoa dan sholat ghoib mendoakan Pak Habibie yang meninggal kemarin. Hari ini saya berkesempatan untuk melihat, karena banyak cerita di salah satu Lebak ini ada Negeri Di Atas Awan. Saya kebetulan juga program pemerintah Provinsi sedang membangun jalan dan men-cor jalannya kurang lebih 16 kilometer. Sekarang sudah bisa akses masuk ke sini kendaraan dan tempatnya bisa dibuktikan dalam gambar ini indah sekali seperti kita berada di dunia lain seperti di pesawat. Jadi menarik saya juga sebagai daerah wisata. Demikian insya Allah baik bagi masyarakat Banten. Selamat pagi menarik dan selamat menikmati suasana awan yang menghampar..."

Rupanya pesan sederhana tersebut mampu menjadi kekuatan sebagai sumber berita. Berita atau news menurut Hearst seperti dikutip McKane (2006:1) "news is something somebody want suppressed - all the rest is advertising." Ada unsur kejutan dari peristiwa tersebut yaitu tempat wisata yang menarik minat sehingga baik untuk di-sharing ke teman lainnya dari anggota grup WA. Begitu pun media massa baik konvensional maupun media online dengan sukacita meyajikannya sebagai sebuah berita karena memiliki unsur nilai berita yang tinggi. Ini menunjukkan komunikator memiliki kredibilitas tinggi atau dapat dipercaya dalam menyampaikan isi pesannya karena di hari yang sama, 19 September 2019 pernyataan komunikator tersebut beredar secara viral, dari satu orang ke orang lain yag tergabung dalam satu grup kemudian diteruskan kembali ke rekan lainya sehingga tayangan mengenai tempat wisata baru tersebut berantai beredar.

Kredibilitas komunikator menurut McCroskey dalam An Introduction to Rhetorical communication dikutip Mulyana (2007) terdiri tiga kriteria yaitu, ortoriter atau keahlian, karakter atau watak, dan kedinamisan. Pernyataan komunikator yang ternyata Gubernur Banten Wahidin Halim, nama diketahui dari pemberitaan media online yang mencantumkan nama komunikatornya, memiliki ketiga kriteria tersebut. Pertama, komunikator memiliki keahlian dalam menyampaikan isi pesan komunikasinya walaupun disajikan seperti seorang reporter televisi, namun karena ia seorang gubernur yang terbiasa beretorika atau berorasi sehingga pesannya jelas dan mampu mengajak pendengar untuk mencermati pesan apa yang disampaikannya.

Kedua, karakter watak sebagai komunikator yang berdarah Banten ini menjadi kekuatan kredibilitasnya karena kedekatannya dengan wilayah yang sedang dipaparkan, seperti sedang berpromosi mengenai tempat wisata baru agar publik mengenal dan mendatanginya.

Ketiga, kedinamisan dari komunikator melalui bantuan kamera, komunikator memaparkan dengan menunjuk kea rah pemandangan yang menakjubkan bagi orang yang baru melihatnya yaitu sekumpulan awan yang terlihat dekat dengan pandangan.

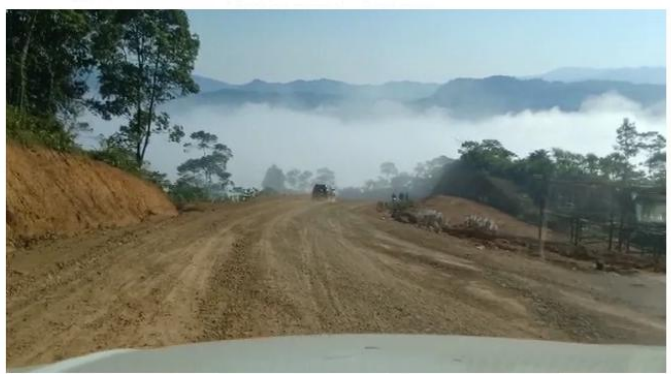

Sumber: sharing WA grup

Gambar 4:

Pesan Komunikator di WA Grup menjelaskan perjalanan ke Citorek 
Pada WA grup (gambar 4) di-share juga mengenai pesan narasi komunikator yang menggambarkan jalan menuju lokasi masih dalam perbaikan, walaupun jalan yang lebar menuju lokasi namun terlihat masih tanah dan berdebu. Pesan komunikator disampaikannya dari kendaraan yang digunakan saat menuju lokasi. Tayangan dan narasi tersebut menggambarkan situasi terbaru yang menjelaskan bahwa kondisi jalan belum sempurna.

Di hari yang sama, setelah tayangan tersebut diunggah ke media sosial, media online berbasis internet pun ramai menampilkan sosok komunikator seperti yang beredar di WA grup namun dilengapi dengan nama jelas komunikator sehingga publik pembaca dapat mengenai siapa komunikator tersebut. Satu diantaranya dimuat oleh WartaKota.com melalui akun YouTube.

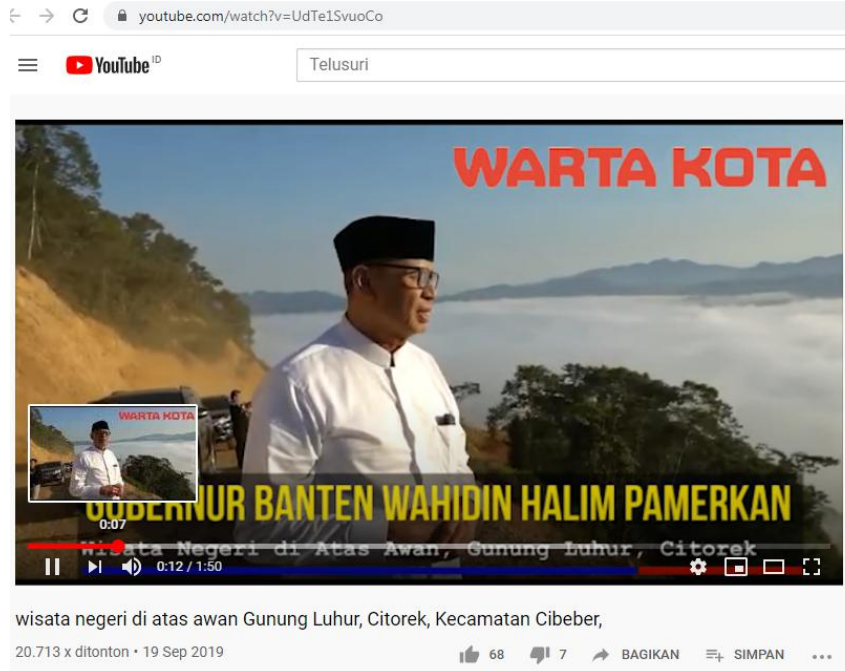

Sumber: WartaKota.com di YouTube

Gambar 5: Komunikator adalah Gubernur Banten Wahidin Halim

Destinasi wisata Negeri di Atas Awan di Desa Citorek Kidul menjadi geger dan ramai dikunjungi gegara pesan viral melalui media sosial. Menurut Kompas.com, waktu yang paling pas mengunjunginya sekitar pukul 05.30-07.00. dari Jakarta menuju Rangkas Bitung kemudian ke arah Wewengkon Citorek. Diperkirakan memerlukan waktu tempuh sekitar 4 jam dari Jakarta. Tiket masuknya Rp 5.000. Pengunjung bisa menikmati pemandangan awan terlihat dari ketinggian Gunung Luhur yang berkisar 901 meter di atas permukaan laut (mdpl). Keunikan lain yang dimiliki desa ini adalah tradisi nenek moyang layaknya masyarakat Suku Baduy. Akan tetapi, masyarakat adat Citorek hampir sama dengan masyarakat adat Cisungsang yakni, lebih terbuka kepada dunia luar.

Masih menurut penuturan Kompas.com, masyarakat Desa Citorek juga sangat menjunjung para sesepuh atau pemimpin adat tertinggi. Selain itu, masih memegang teguh adat istiadat meskipun tidak tertulis. Salah satu tradisi yang masih dilaksanakan oleh masyarakat adat Citorek hingga kini adalah tradisi tanam padi. Masyarakat Citorek memiliki tradisi tanam padi yang mereka sebut dengan tradisi Seren Taun. Tradisi ini adalah bentuk rasa syukur masyarakat pasca-panen terhadap Tuhan. Masyarakat ini menganut kepemimpinan tiga unsur yakni negara (lura/jaro), karhuhun (kasepuhan/kaolotan) dan agama (penghulu). Tiga unsur inilah yang kemudian membentuk sistem sosial yang menjunjung peninggalan leluhur dan selalu mengedepankan kelestarian lingkungan. Desa Citorek juga memiliki aturan adat yang disebut leuwung kolot. Istilah tersebut merupakan penyebutan bagi hutan tua atau hutan lindung.

Daya tarik komunikator dengan dukungan komunikasi visualnya menjadi viral di media sosial serta dukungan publikasi media online menarik banyak minat pengunjung beramairamai ke Citorek di hari yang sama. Aibatnya, terjadi kemacetan luar biasa sehingga kembali ramai menjadi pemberitaan di media sosial bahkan media online pun turut menurunkan beritanya. Seperti diberitakan Dwi Prasetya, Merdeka.com 23 September 2019 


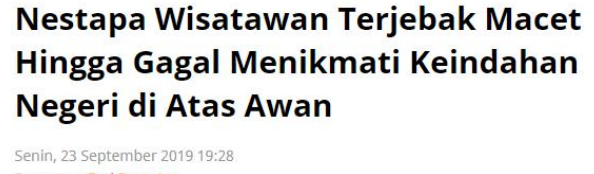

Senin, 23 September 2019 19:2

Reporter: Dwi Prasetya

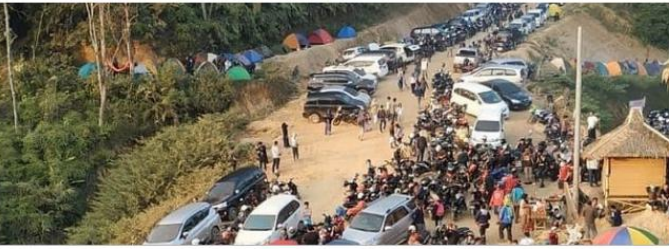

Sumber: Merdeka.com

Gambar 6. Kemacetan kendaraan dan kerumunan orang di Negeri DI atas Awan

https://www.merdeka.com/peristiwa/sempat-hits-dan-viral-di-medsos-wisata-negeri-di-atas-awanditutup-sementara.html.

Kehadiran masyarakat di lokasi wisata Citorek pada Minggu, 22 September 2019, empat hari setelah pesan komunikator mengudara dan mendarat di media sosial, akhirnya lebih banyak memberikan pesan komentar yang kurang menyenangkan. Seperti tergambarkan melalui isi berita Merdeka.com berikut ini.

Merdeka.com - Wisata Negeri di atas awan di Gunung Luhur, Citorek, Kabupaten Lebak, Banten mendadak diserbu puluhan ribu pengunjung usai viral di media sosial, Minggu (22/9) kemarin. Kondisi ini menyebabkan kemacetan hingga 7 kilometer sehingga para pengunjung yang berangkat malam tidur dan beristirahat di perjalanan. Nahasnya lagi, mereka yang sudah sampai di dekat lokasi pun gagal menikmati hamparan keindahan awan lantaran penuh dan berdesakdesakan. Salah satu wisatawan yang terpaksa gigit jari tidak bisa menikmati pemandangan keindahan Gunung Luhur Citorek adalah wisatawan asal Serang, Tusnedi. Padahal, dia mengaku telah berangkat dini hari untuk menikmati wisata alam yang sedang hits tersebut. "Jam 5 pagi para pengunjung berebut naik ke bukit agar mendapat pemandangan seperti yang di tv-tv. Banyak yang nekat melalui jalur pintasan yang berbahaya. Kondisi sangat padat. Enggak kurang dari 10 ribu orang. Saya sendiri enggak bisa naik ke atas karena penuh dan berdesak-desakan," kata Tusnedi saat dihubungi wartawan, Senin (23/9). Menurutnya, suasana dan gambaran di wisata awan Gunung Luhur bagus dan indah seperti gambar yang viral di medsos. Sayangnya, keindahan alam tersebut tidak dibarengi dengan kesiapan dan pengelolaan yang baik dari pemerintah daerah. "Pukul 07.00 WIB, kendaraan roda 2 dan para pengunjung mulai turun dan bersiap untuk pulang. Tapi ketika ngeliat kendaraan di parkiran sudah stag. Kondisinya 2 jalur sudah dipadati oleh kendaraan yang datang. Sehingga motor pun enggak bisa bergerak," kata dia. Kendaraan baru bisa jalan pukul 11.00 WIB setelah alat berat membuka jalur parkiran baru agar kendaraan yang menghalangi masuk ke area wisata bisa bergerak. "Itu pun perkebunan warga yang diubah jadi lahan parkir dadakan," katanya. [gil]

Belajar dari kecepatan viral media sosial WA, kegiatan komunikasi pemasaran pariwisata harus dirancang baik terutama memperhatikan kesiapan prasarana di tempat tujuan. Upaya komunikasi Gubernur Banten sangat efektif dan efisien, namun diluar dugaan animo masyarakat sangat tinggi sehingga terjadi peristiwa kemacetan yang panjang. Peristiwa ini akhirnya menumbuhkan image negatif bagi pengunjung karena pesan yang ditawarkan yang mereka dapatkan tidak seperti kenyataan. Kecepatan media sosial dapat memberikan effect luar biasa. Seperti model jarum suntik (hyphodermic needle) Elihu Katz atau the bullet theory (Campbell: 518). That concept that powerful media affect weak audiences.

Rumusan masalah deskriptif dan naratif adalah mengekplorasi atau memotret situasi sosial secara mendalam mengenai peristiwa di Citorek, Banten, dimana komunikator memiliki nilai kredibilitas yang didukung visual mengenai objeknya yaitu kumpulan pesona awan yang berada di bawah tempat kita berdiri, maka pesan tersebut memiliki sentuhan emosional yang menyentuh dan menumbuhkan pesona menarik bagi yang melihatnya. Seusai mendapat pesan tersebut mereka rela men-sharing dan mengajak rekan kelompoknya berkunjung. Isi tayangan 
video memberikan pesan kredibilitas komunikator melalui tayangan komunikasi visual akan lebih mengukuhkan pesan yang disampaikan seperti saat menyampaikan pesan mengenai objek menawan dan mempersona.

Di era digitalisasi, cara berkomunikasi seperti yang dilakukan Gubernur Banten ini merupakan strategi komunikasi pemasaran yang jitu. Tayangan di upload, kemudian media massa menyebarkan isi beritanya, maka pesan serentak tersebar diterima publik. Tidak heran, kemacetan terjadi karena publik antusias ingin berkunjung untuk menyaksikan keindahan alam Citorek, Banten. Namun demikian, ketidaksiapan prasarana penunjang menyebabkan kekecewaan para pengunjung. Dengan demikian, perlu kematangan saat akan menyampaikan pesan dengan memperhitungkan dampak yang terjadi jika pesan tersebar luas.

\section{SIMPULAN}

Penelitian mengenai peristiwa yang terjadi di Citorek, Banten, menggambarkan pesan komunikasi yang disampaikan melalui media, seperti media massa atau pun media sosial senantiasa memiliki kekuatan mempengaruhi komunikan. Dalam peristiwa penelitian ini, pesan komunikator memberikan dampak luar biasa layaknya teori stimulus respon atau pun the bullet theory. Penyebaran pesan komunikasi visual melalui instant messaging WA kemudian menjadi viral mampu mewujudkan nilai berita baik bagi publik yang menerima pesan dari $W A$, begitu pu media massa dan media online, peristiwa tersebut menjadi layak berita karena memiliki nilai berita yang tinggi.

Wajar, akhirnya banyak media turut memberitakan pesan komunikator tersebut yang ternyata adalah Gubernur Banten yang tentunya memiliki nilai kredibel bagi sumber berita media massa. Bahkan, media online pun dengan utuh menampilkan suguhan tayangan komunikator di portal medianya yang berafiliasi dengan media You-Tube. Dalam kegiatan marketing public relations, cara atau strategi jitu ini menjadi pilihan baik dalam berkomunikasi sehingga publik cepat mengetahui adanya peristiwa. Namun demikian, yang memberikan daya tarik, unik, luar biasa sehingga menarik disimak, diperhatikan para komunikan. Mereka bisa saja tidak terpengaruh siapa komunikatornya, karena dalam videonya tidak menjelaskan siapa dirinya. Setelah media massa dan media online ramai memberitakan tayangan komunikator tersebut, pesan komunikasi viral tersebut semakin kredibel. Komunikatornya memiliki unsurunsur keahlian, karakter, dan kedinamisan.

Dengan demikian, memanfaatkan media instant messaging dalam menyampaikan pesan menjadi alternatif dikreasikan dengan baik dan dapat dipertanggungjawabkan pesannya sehingga tidak membohongi masyarakat luas. Fenomenal wisata Negeri Di Atas Awan, Banten, dapat merefleksikan bahwa individu yang menerima pesan visual sangat mudah tergugah dalam mewujudkan motivasinya untuk bertindak dengan cara berkunjung melihat dan membuktikan secara langsung keindahan visual panorama apa yang ramai diperbincangkan di WhatsApp. Baik sekadar untuk selfie maupun menunjukkan eksistensinya sebagai traveler yang sudah berkunjung ke destinasi tersebut. Aktualisasi diri menjadi motivasi dirinya dengan meng-upload visual yang ada di kelompoknya.

Fenomena kemacetan wisatawan yang terjadi merefleksikan kembali kepada teori hyphodermic needle, pesan yang menarik dapat membius komunikan. Mengingatkan effect media radio terhadap siaran drama radio War of the Worlds karya Orson Welles (1938) yang membuat heboh atau kepanikan penduduk di wilayah Grover's Mill, New Jersey, tempat peristiwa yang dijadikkan setting cerita terjadinya invasi mahluk Mars ke Bumi. Namun demikian, riuhnya peristiwa di Banten bukan karena panik tetapi karena antusiasnya wisatawan berkunjung ke lokasi yang infrastrukturnya belum selesai. Seperti disampaikan komunikator melalui tayangan videonya. Namun, pesan tersebut tidak terpahami. Peristiwa tersebut juga menunjukkan adanya kekuatan pesan sesuai teori Ivan Pavlov, menumbuhkan stimulus respon.

Media WhatsApp sebagai media sosial instant messaging menjadi dambaan masyarakat Indonesia karena dapat memberikan berbagai kesenangan bagi pemilik aplikasi tersebut. Kelengkapan fitur seperti interaksi melalui komunikasi antarpribadi secara visual antar pengguna merupakan kekuatan dan kelebihan media ini, Selain itu, tayangan video yang dapat di-upload kemudian mudah diteruskan ke pengguna WA lainnya sehingga menjadi viral, media 
ini menjadi andalan dan alasan masyarakat memilih menggunakannya. Temuan lain, menegaskan bahwa media sosial dapat menjadi inspirasi atau mengajak serta media massa untuk menjadi materi berita di medianya melalui nilai berita. Di beberapa program acara tv Indonesia, banyak ditemui program yang diambil dari tayangan yang sumbernya dari media sosial seperti unik, lucu, menegangkan, yang menurut mereka memiliki nilai berita bagi pemirsanya sehingga menjadi nilai jual bagi para pemasang iklan. Keterbatasan penelitian masih bersifat eksploratoris sehingga masih memiliki kekurangan dalam kedalaman teoritis dan memerlukan investigasi penelitian yang deskriptif atau eksplanatif. Penelitian hanya bersumber pada suatu objek pariwisata sehingga tidak dapat digeneralisasikan untuk objek pariwisata yang lain.

\section{DAFTAR PUSTAKA}

Bedford. C., William D., Brewer. B. M. (2002). Principles and Methods of Social Research, $2^{\text {nd }}$ ed. Mahwah : Lawrence Erlbaum Associates

Bryman, Alan and Becker, Saul. (2012). Qualitative Research. Bristol. Policy Press

Campbell, R., Martin R. C., Fabos B. (2016). Media \& Culture.Mas communication in A Digital Age. New York: Bedford/St. Martin's

Cao, Xian., Bin Yu, Xiao-Xia Tian Tian. (2017). The Effect of Social Media on tourism Consumer Adoption Intention.: Evidence from Urumqi. Journal of Accounting \& Marketing. Sumber: https://www.semanticscholar.org/paper/The-Effect-of-SocialMedia-on-Tourism-Consumer-from-Cao

Yu/83ccfbea2cefa61fbd10162520b65adfbbb7b56f\&prev=search\&pto=aue diakses 2 Juli 2020

Dailysocial. (2019). Sumber: https://dailysocial.id/post/apa-itu-whatsapp diakses 10 November 2019

Daymon, Christine, Immy Holloway. (2008). Riset Kualitatif dalam Public Relations dan Marketing Communication (terj. Cahya Wiratama). Yogyakarta : Bentang

Dewdney, Andrew, Peter Ride. (2006). The New Media Handbook. Abingdon : Routledge

Dwi Prasetya, Sumber: https://databoks.katadata.co.id/datapublish/2017/08/29/penggunaponsel-indonesia-mencapai-142-dari-populasi diakses 8 November 2019

Harjanto, Rudy. (2009). Prinsip Prinsip Periklanan. STIKOM ITKP. The School of Advertising. Jakarta

Harrison, Helena; Birks, Melanie; Franklin, Richard \& Mills, Jane. (2017). Case Study Research: Foundations and Methodological Orientations. Jurnal FQS (Forum: Qualitative Social Research). Volume 18, No. 1, Art. 19 January 2017. Sumber: http://www.qualitativeresearch.net/index.php/fqs/article/view/2655/4079. Diakses 2 Juli 2020

Kerin, Roger, Steven W. Hartley, William Rudelius. (2013). Marketing. New York: McGraw-Hill Irwin

Kovacic, Melita Poler, Karmen Erjave, Katarina Stular. (2010). Credibility of Traditional vs. Online News Media: A Historical Change in Journalists Perceptions

Kumparan. (2020). Sumber: https://kumparan.com/kumparantech/perjalananblackberry-messenger-disukai-dijual-lalu-ditinggalkan-1quw4r7IFAw diakses 1 Juli 2020

McKane, Anna. (2006). News Writing. London: Sage Publication

Merdeka. (2019). Sumber: https://www.merdeka.com/peristiwa/sempat-hits-dan-viral-dimedsos-wisata-negeri-di-atas-awan-ditutup-sementara.html diakses 2 Juli 2020

Mulyana, Deddy. (2007) IImu Komunikasi: Suatu Pengantar. Bandung: Rosda Karya

Neuman, W. Lawrence. (2006). Social Research Methods : Qualitative and Quantitative Approaches, $6^{\text {th }}$ ed. Boston : Pearson

Pasa, Sartika Sari Wardanhi DH. (2011). Jurnal Kareba. Volume 1 No. 4. Oktober - Desember 2011. Sumber: http://journal.unhas.ac.id/index.php/kareba/article/view/325

Rahartri. (2019) "WhatsApp" Media Komunikasi Efektif Masa Kini (Studi Kasus Pada Layanan Jasa Informasi IImiah di Kawasan PUSPIPTEK). Visi Pustaka Vol 21, No. 2, Agustus 
2019. Sumber: http://garuda.ristekbrin.go.id/documents/detail/1267849. Diakses 2 Juli 2020

Rakhmat, Jalaluddin. (2016). Metode Penelitian Komunikasi: Dilengkapi Contoh Analisis Statistik Dan Penafsirannya. Simbiosa Rekatama Media. Bandung

Silvia, Paramita S., (2018). Kredibilitas Komunikator Dalam Menyampaikan Pesan (Analisis Opini Generasi Milenial Pada Kepala Penerangan Kodam Jaya). Koneksi. Vol. 2 No. 2, Desember 2018, Hal. 569-576 diakses 3 Juli 2020

Tribunnews. (2015). Sumber: https://jogja.tribunnews.com/2019/06/26/riset-cuponationwhatsapp-jadi-aplikasi-chatting-terpopuler-di-indonesia

Trisnani. (2017). Pemanfaatan WhatsApp Sebagai Media Komunikasi dan Kepuasan Dalam Penyampaian Pesan Dikalangan Tokoh Masyarakat. Jurnal Komunikasi, Media dan Informatika, Volume 6 Nomor 3, November 2017. Sumber: http://garuda.ristekbrin.go.id/journal/ KOMUNIKA. Diakses 2 Juli 2020

Utami, Pratiwi. (2017). The Role of Viral Video in Indonesia. Jurnal Masyarakat dan Budaya. Vol. 19 No. 3 (2017) http://jmb.lipi.go.id/index.php/jmb/article/view/548/357

Wardani, Agustin Setyo. (2019) Sumber: https://www.liputan6.com/tekno/read/3998745/ini-5aplikasi-chatting-terpopuler-di-indonesia. Diakses 5 November 2019

Wardhana, Aditya, Mahir Pradana. (2016). Viral Marketing Determinants of Top Online Shop Brands in Indonesia. Mimbar. Vol. 23. Number 1 (June, 2016). Sumber: https://www.researchgate.net/profile/Mahir_Pradana2/publication/311100851ndonesia

Whiting, A., Williams, D. (2013). Why People Üse Social Media: a uses and gratification approach. Qualitative Market Research: An International Journal, Vol. 16 No. 4. Sumber: https://www.emerald.com/insight/content/doi/10.1108/QMR-06-2013-0041/full/html diakses 30 Juni 2020 